\title{
Article
}

Mycosphere

\section{Dendryphiella fasciculata sp. nov. and notes on other Dendryphiella species}

\author{
Liu $\mathrm{NG}^{1,2}$, Hongsanan $\mathrm{S}^{3}$, Yang $\mathrm{J}^{3}$, Lin $\mathrm{CG}^{3}$, Bhat $\mathrm{DJ}^{4}$, Liu $\mathrm{JK}^{1}$, Jumpathong \\ $\mathrm{J}^{2,5}$, Boonmee $\mathrm{S}^{3}$, Hyde $\mathrm{KD}^{3}$ and Liu $\mathrm{ZY}^{1^{*}}$ \\ ${ }^{1}$ Guizhou Key Laboratory of Agricultural Biotechnology, Guizhou Academy of Agricultural Sciences, Guiyang, 550006, \\ China \\ ${ }^{2}$ Faculty of Agriculture, Natural Resources and Environment, Naresuan University, Phitsanulok, 65000, Thailand \\ ${ }^{3}$ Center of Excellence in Fungal Research, Mae Fah Luang University, Chiang Rai, 57100, Thailand \\ ${ }^{4}$ Azad Housing Society, No. 128/1-J, Curca, P.O. Goa Velha 403108, India \\ ${ }^{5}$ Center for Agricultural Biotechnology, Naresuan University, Phitsanulok, 65000, Thailand
}

Liu NG, Hongsanan S, Yang J, Lin CG, Bhat DJ, Liu JK, Jumpathong J, Boonmee S, Hyde KD, Liu ZY 2017 - Dendryphiella fasciculata sp. nov. and notes on other Dendryphiella species. Mycosphere 8(9), 1575-1586, Doi 10.5943/mycosphere/8/9/12

\begin{abstract}
Dendryphiella is an asexual morph genus placed in the family Dictyosporiaceae. During our study on brown-spored hyphomycetes, a new taxon D. fasciculata was found on decaying wood collected in Chiang Mai Province, Thailand. The new species is characterized by mononematous, fasciculate conidiophores with polytretic, terminal and intercalary conidiogenous cells. Conidia are fusiform to ellipsoidal, pale brown and aseptate when young, becoming brown or dark brown, verrucose and 3-septate when mature. The phylogenetic analysis of combined ITS and LSU sequence data showed that isolates of Dendryphiella form a well-supported clade in Dictyosporiaceae, and Dendryphiella fasciculata is phylogenetically distinct from other species. Dendryphiella fasciculata is therefore introduced here with a description and morphological illustrations. Taxonomic notes and a key to Dendryphiella species are provided.
\end{abstract}

Key words - asexual morph - Dictyosporiaceae - Phylogeny - Pleosporales

\section{Introduction}

The family Dictyosporiaceae was first mentioned in Liu et al. (2015) and Boonmee et al. (2016) validly introduced the family based on type genus, Dictyosporium Corda. The asexual morph genera in Dictyosporiaceae are characterized by sporodochial, punctiform or effuse colonies, mononematous, hyaline to brown conidiophores, with reduced to standard and blastic or tretic conidiogenous cells, and cheiroid or fusiform conidia with or without appendages (Goh et al. 1999, Cai et al. 2002, Liu et al. 2015, Boonmee et al. 2016). Some genera have been linked to their sexual morphs, such as Dictyosporium and Pseudocoleophoma Kaz. Tanaka \& K. Hiray (Liu et al. 2015, Tanaka et al. 2015).

The genus Dendryphiella was established by Ranojevic (1914) with the type species $D$. interseminata (Berk. \& Ravenel) Bubák. The genus is characterized by macronematous conidiophores with polytretic, integrated conidiogenous cells at the swollen tip and at intercalary 
swellings and catenate or solitary conidia (Ellis 1971, Matsushima 1971, Rai \& Kamal 1986, Guo \& Zhang 1999, Crous et al. 2014, 2016). Reisinger (1968) introduced D. vinosa (Berk. \& Curt.) Reisinger and Matsushima (1971) synonymized D. interseminata under this species based on morphology. Hughes (1953) treated Dendryphiella as a synonym of Dendryphion Wallr. as he considered that the looser and longer branched conidiophores are not sufficient characters for keeping this genus as distinct. Nicot (1958) described a new species, Dendryphiella arenaria Nicot and re-established Dendryphiella as a distinct genus. Ellis (1971) agreed with this viewpoint. Currently no Dendryphiella species have been linked with their sexual morphs (Wijayawardene et al. 2012).

Two marine species, Dendryphiella arenaria and D. salina (G.K. Sutherl.) Pugh \& Nicot were described as conspicuous, cosmopolitan dematiaceous hyphomycete taxa which commonly occur in sea-water foam and marine sediments, as well as on macro-algae and decaying plant debris (Kohlmeyer 1966, Kirk 1983, Jones et al. 2015). Ellis (1976) transferred Dendryphiella to the genus Scolecobasidium Abbott apparently based on the character of polyblastic, denticulate, conidiogenous cells that appear as denticles when the conidia become detached (Ellis 1976). However, subsequent mycologists (Kohlmeyer \& Kohlmeyer 1979, Jones et al. 2008) did not observe this distinct morphology in this genus. Woudenberg et al (2013) provided a phylogenetic analysis based on SSU, LSU and RPB2 sequence data. In their study, Dendryphiella salina was equated with Embellisia annulata de Hoog, Seigle-Mur., Steiman \& K.-E. Erikss. Moreover, Dendryphiella arenaria and D. salina formed a well-supported clade in Pleosporaceae, while the type species D. vinosa was placed in the family Dictyosporiaceae (Woudenberg et al. 2013, Boonmee et al. 2016). Thus, a new genus Paradendryphiella Woudenb. \& Crous, typified by $P$. salina (G.K. Sutherl.) Woudenb. \& Crous, was established to accommodate these two species (Woudenberg et al. 2013, Jones et al. 2015). Another two species, D. eucalyptorum Crous \& E. Rubio and D. paravinosa Crous \& Guarnaccia were introduced based on distinct morphology and phylogenetic evidence in the recent studies (Crous et al. 2014, Crous et al. 2016). In this study, eleven species are compiled in this genus.

During ongoing surveys of brown-spored hyphomycetes, a new species of Dendryphiella was collected. Detailed morphological study and molecular analysis of combined ITS and LSU sequence data indicated that Dendryphiella fasciculata was a phylogenetically distinct species and clustered together with three other Dendryphiella species. All reside in Dictyosporiaceae. In this study, we introduce a new species and provide notes on Dendryphiella species with an updated taxonomic key.

\section{Materials \& Methods}

\section{Collections and examination of specimens}

Specimens of decaying woody litter were collected from Chiang Mai Province, Thailand in September 2016 and taken to the laboratory in Ziplock plastic bags. The samples were incubated in plastic boxes with sterile and moist tissue at $25-30{ }^{\circ} \mathrm{C}$ for 3 days. The samples were examined following the methods described in Phookamsak et al. (2014) under a Motic SMZ 168 Series dissecting microscope. The morphological characters were studied with the fruiting bodies mounted in a drop of water and photographed by a Nikon ECLIPSE 80i compound microscope fitted with a Cannon 600D digital camera. Measurements were performed using the Tarosoft (R) Image Frame Work software and photo plate was made using Adobe Photoshop CS3 software (Adobe Systems, USA).

Fungal isolation was performed using the single spore isolation method described in Chomnunti et al. (2014). Specimens are deposited in the herbarium of Mae Fah Luang University (MFLU), Chiang Rai, Thailand and the herbarium of Cryptogams Kunming Institute of Botany Academia Sinica (HKAS), Kunming, China. Pure cultures are deposited in the Mae Fah Luang University Culture Collection (MFLUCC), Chiang Rai, Thailand. Faces of fungi (FOF) numbers and Index Fungorum numbers are acquired as in Jayasiri et al. (2015) and Index Fungorum (2017). 


\section{DNA extraction, PCR amplification and sequencing}

Fresh mycelia were scraped from the pure cultures growing on PDA after one month at 25 ${ }^{\circ} \mathrm{C}$. DNA was extracted using DNA Extraction Kit (Sangon Biotech) from fresh fungal mycelia. Two gene fragments, internal transcribed spacer (ITS) and large subunit rDNA (28S, LSU), were amplified by the primer pairs ITS5 and ITS4 (White et al. 1990), and LROR and LR5 (Vilgalys \& Hester 1990) respectively. Polymerase chain reaction (PCR) was carried out in $25 \mu \mathrm{l}$ reaction volume containing $12.5 \mu \mathrm{l} 2 \times$ PCR Master Mix (TIANGEN Co., China), $9.5 \mu \mathrm{l} \mathrm{ddH}_{2} \mathrm{O}, 1 \mu \mathrm{l}$ of each primer and $1 \mu \mathrm{l}$ DNA template. The amplification condition for both ITS and LSU regions followed Yang et al. (2015) The PCR products are examined using 1\% agarose electrophoresis gel stained with ethidium bromide. Purified PCR products were sequenced by commercial company Invitrogen Biotechnology Co., Ltd (Shanghai, P. R. China).

\section{Phylogenetic analysis}

Related strains in Dictyosporiaceae for phylogenetic analyses listed in Table 1 were obtained using the Blast process at NCBI (National Center for Biotechnology Information) and from recent relevant publications (Jones et al. 2008, Crous et al. 2014, Boonmee et al. 2016, Crous et al. 2016, Wang et al. 2016). Sequences were aligned using online MAFFT version 7 (Katoh \& Standley 2013). Single gene analyses were performed and trees were used to check the conflict of these two gene regions, and then two genes were combined using BioEdit (Hall 1999). The alignments were checked visually and optimized manually using AliView (Larsson 2014) and BioEdit (Hall 1999) where necessary.

Table 1 DNA sequences used for the phylogenetic tree (newly generated sequences are indicated in bold, ex-type strains are indicated in * after collection number)

\begin{tabular}{|c|c|c|c|}
\hline \multirow[t]{2}{*}{ Species name } & \multirow[t]{2}{*}{ Strain number } & \multicolumn{2}{|c|}{$\begin{array}{c}\text { GenBank Accession } \\
\text { Numbers }\end{array}$} \\
\hline & & ITS & LSU \\
\hline Aquaticheirospora lignicola & RK 2006a* & AY864770 & AY736378 \\
\hline Dendryphiella eucalyptorum & CPC 22927* & KJ869139 & KJ869196 \\
\hline Dendryphiella paravinosa & CPC 26176* & KX228257 & KX228309 \\
\hline Dendryphiella vinosa & & & EU848590 \\
\hline Dendryphiella fasciculata & MFLUCC 17-1074 & MF399213 & MF399214 \\
\hline Dictyocheirospora aquatica & KUMCC $15-0305^{*}$ & KY320508 & KY320513 \\
\hline Dictyocheirospora bannica & $\mathrm{KH} 332^{*}$ & LC014543 & AB807513 \\
\hline Dictyocheirospora garethjonesii & MFLUCC 16-0909* & KY320509 & KY320514 \\
\hline Dictyocheirospora pseudomusae & KH 412 & LC014549 & AB807516 \\
\hline Dictyocheirospora pseudomusae & yone $234 *$ & LC014550 & AB807520 \\
\hline Dictyocheirospora rotunda & MFLUCC 14-0293* & KU179099 & KU179100 \\
\hline Dictyosporium alatum & ATCC34953* & NR077171 & DQ018101 \\
\hline Dictyosporium elegans & NBRC $32502 *$ & DQ018087 & DQ018100 \\
\hline Dictyosporium meiosporum & MFLUCC 10-0131* & KP710944 & KP710945 \\
\hline Dictyosporium olivaceosporum & KH $375^{*}$ & LC014542 & AB807514 \\
\hline Dictyosporium sexualis & MFLUCC 10-0127* & KU179105 & KU179106 \\
\hline Dictyosporium stellatum & CCFC $241241^{*}$ & JF951154 & JF951177 \\
\hline Dictyosporium thailandicum & MFLUCC 13-0773* & KP716706 & KP716707 \\
\hline Digitodesmium bambusicola & CBS $110279 *$ & DQ018091 & DQ018103 \\
\hline Gregarithecium curvisporum & KT $922 *$ & AB809644 & AB807547 \\
\hline
\end{tabular}




\begin{tabular}{llll} 
Jalapriya inflata & NTOU 3855 & JQ267362 & JQ267363 \\
Jalapriya pulchra & MFLUCC 15-0348* & KU179108 & KU179109 \\
Jalapriya toruloides & CBS 209.65 & DQ018093 & DQ018104 \\
Paradendryphiella arenariae & CBS 181.58* & KF156010 & KC793338 \\
Paradendryphiella salina & CBS 142.60 & DQ411540 & KC793339 \\
Pseudocoleophoma calamagrostidis & KT 3284* & LC014592 & LC014609 \\
Pseudocoleophoma polygonicola & KT 731* & AB809634 & AB807546 \\
Pseudocoleophoma typhicola & MFLUCC 16-0123* & KX576655 & KX576656 \\
Pseudodictyosporium elegans & CBS 688.93* & DQ018099 & DQ018106 \\
Pseudodictyosporium wauense & NBRC 30078 & DQ018098 & DQ018105 \\
\hline
\end{tabular}

Maximum likelihood analysis was performed using CIPRES web portal (Miller et al. 2010) using RAxML-HPC BlackBox tool and the default GTRGAMMA + I model. The tree search included 1000 non-parametric bootstrap replicates and the best scoring tree was selected from suboptimal trees under the GTRGAMMA + I substitution model. The resulting replicates were plotted on to the best scoring tree obtained previously.

Maximum parsimony analysis was performed with the heuristic search in PAUP v. 4.0b10 (Swofford 2002). Gaps in the alignment were treated as missing characters and all characters were unorderd. Maxtrees were unlimited, branches of zero length were collapsed and all multiple, equally parsimonious trees were saved. Clade stability was assessed using a bootstrap (BT) analysis with 1000 replicates, each with 10 replicates of random stepwise addition of taxa (Hillis \& Bull 1993).

Bayesian analyses were carried out using MrBayes 3.2 (Ronquist et al. 2012). The best-fit evolutionary model was selected using MrModeltest 2.2 (Nylander 2004). Posterior probabilities (PP) (Rannala \& Yang 1996) were performed by Markov Chain Monte Carlo sampling (MCMC) in MrBayes v. 3.0b4. Bayesian analyses of six simultaneous Markov chains were run for 1000000 generations and trees were sampled every 100th generation (resulting in 10000 total trees). The first 1000 trees, representing the burn-in phase of the analyses, were discarded and the remaining 9000 trees were used for calculating posterior probabilities (PP) in the majority rule consensus tree.

Trees were visualized with FigTree v1.4.2 (Page 1996) and the layout was edited using Adobe Illustrator CS5.

\section{Results}

\section{Phylogenetic analyses}

The alignment of combined ITS and LSU sequence data comprised a total of 1887 characters with gaps (590 for ITS, 1297 for LSU). The dataset composed 30 strains including one newly sequenced taxon and two outgroups, Paradendryphiella arenariae and P. salina (Pleosporaceae). In order to compare the topology of the tree and clade stability, single gene phylogenetic analyses were performed and yielded two trees. The tree topologies are similar between these two trees. Maximum likelihood, maximum parsimony and Bayesian analyses on combined data were performed separately. Tree topologies of these three analyses are similar. The best scoring RA $\times$ ML tree with a final likelihood value of -8310.242789 is presented in Fig. 1. The matrix had 525 distinct alignment patterns with $23.61 \%$ of undetermined characters or gaps. Estimated base frequencies were as follows: $\mathrm{A}=0.244589, \mathrm{C}=0.231709, \mathrm{G}=0.277241, \mathrm{~T}=0.246462$; substitution rates $\mathrm{AC}=1.531992, \mathrm{AG}=2.291657, \mathrm{AT}=2.224229, \mathrm{CG}=0.335383, \mathrm{CT}=$ $6.072279, \mathrm{GT}=1.000000$; gamma distribution shape parameter $\alpha=0.145768$. Maximum parsimony analysis had 343 parsimony informative, 1463 constant, 81 parsimony uninformative characters and yielded 6 most parsimonious trees $(\mathrm{CI}=0.555, \mathrm{RI}=0.701, \mathrm{RC}=0.390, \mathrm{HI}=0.445)$.

The phylogenetic analyses generated by maximum likelihood (ML), maximum parsimony (MP), and Bayesian analysis indicate that Dendryphiella fasciculata is placed within the genus 
Dendryphiella with high support (97\%/89\%/1.00, respectively). The 30 taxa represented nine genera of Dictyosporiaceae with two outgroups. The genus Dendryphiella showed a close phylogenetic relationship with Pseudocoleophoma. The isolate of Dendryphiella fasciculata clustered together with other three of Dendryphiella species. Additionally, Dendryphiella fasciculata formed a distinct lineage and was sister to strain of D. paravinosa.

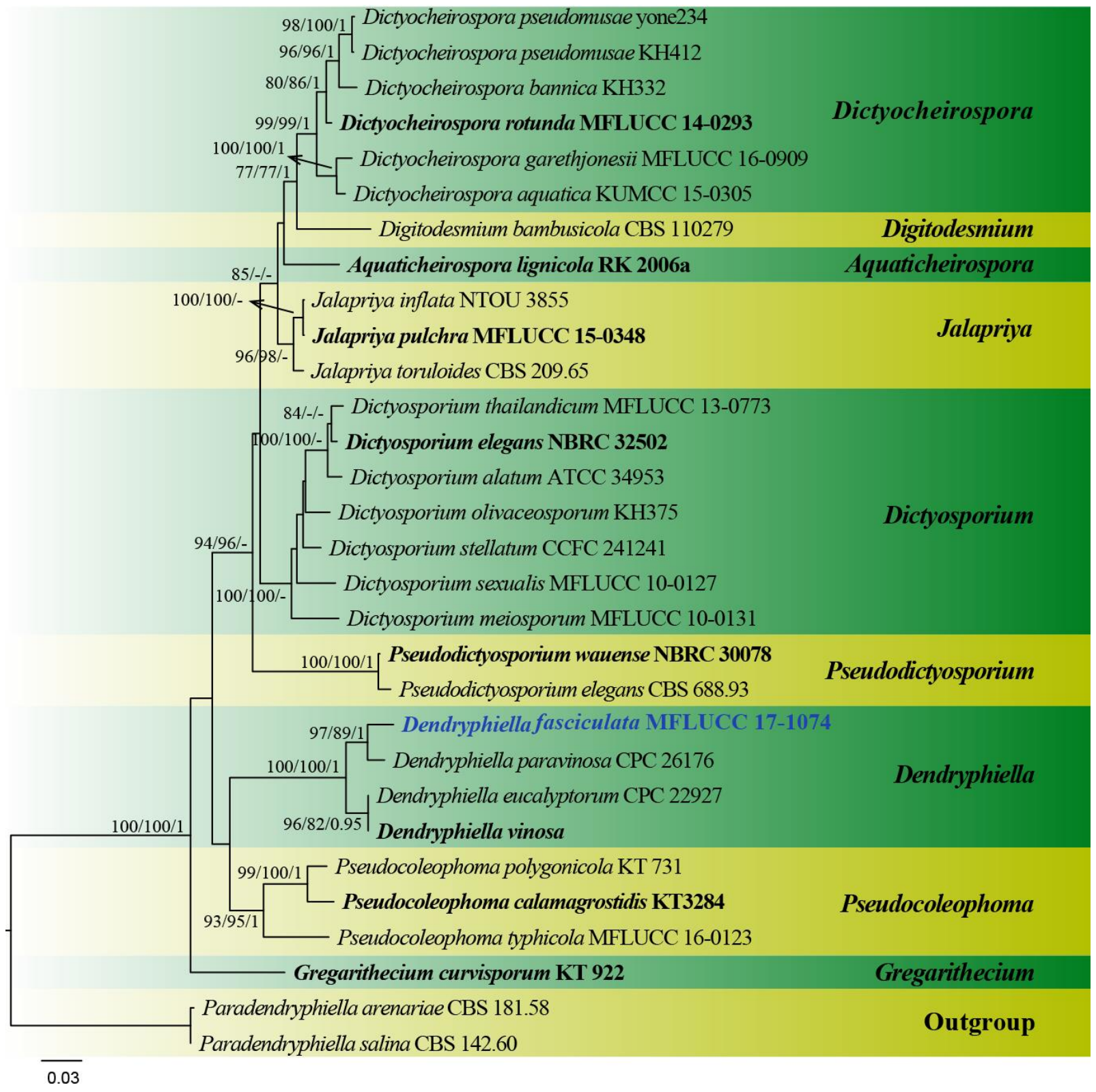

Figure 1 Maximum likelihood (RAxML) tree based on analysis of a combined dataset of ITS and LSU sequence data representing Dictyosporiaceae. Bootstrap support values for ML and MP greater than $75 \%$ and Bayesian posterior probabilities greater than 0.95 are given near nodes respectively. The tree is rooted with Paradendryphiella arenariae and Paradendryphiella salina. The genetic types are indicated in bold and the new isolate is in bold and blue.

\section{Taxonomy}

Dendryphiella fasciculata N.G. Liu, Z.Y. Liu \& K.D. Hyde, sp. nov. 


\section{Holotype - MFLU 17-0748}

Saprobic on decaying wood. Asexual morph Colonies on natural substrate superficial, effuse, greyish brown. Mycelium partly immersed, composed of septate, branched, brown, guttulate, 1.5-2.5 $\mu \mathrm{m}$ wide hyphae. Conidiophores 170-250 $\mu \mathrm{m}$ long, macronematous, mononematous, fasciculate, dark brown at base, slightly paler towards the apex, thick-walled, erect, straight or slightly flexuous, verruculose, septate, unbranched or occasionally branched, wider at the sub-section. Conidiogenous cells $17-33 \mu \mathrm{m}$ long $(\bar{x}=23.86 \mu \mathrm{m}, \mathrm{n}=22)$, polytretic, terminal, later becoming subterminal, proliferating asymmetrically, integrated, brown, verrucose, enlarged at vertex. Conidia $15-30 \times 4.3-7.4 \mu \mathrm{m}(\bar{x}=22.38 \times 5.54 \mu \mathrm{m}, \mathrm{n}=25)$, solitary to catenate, when

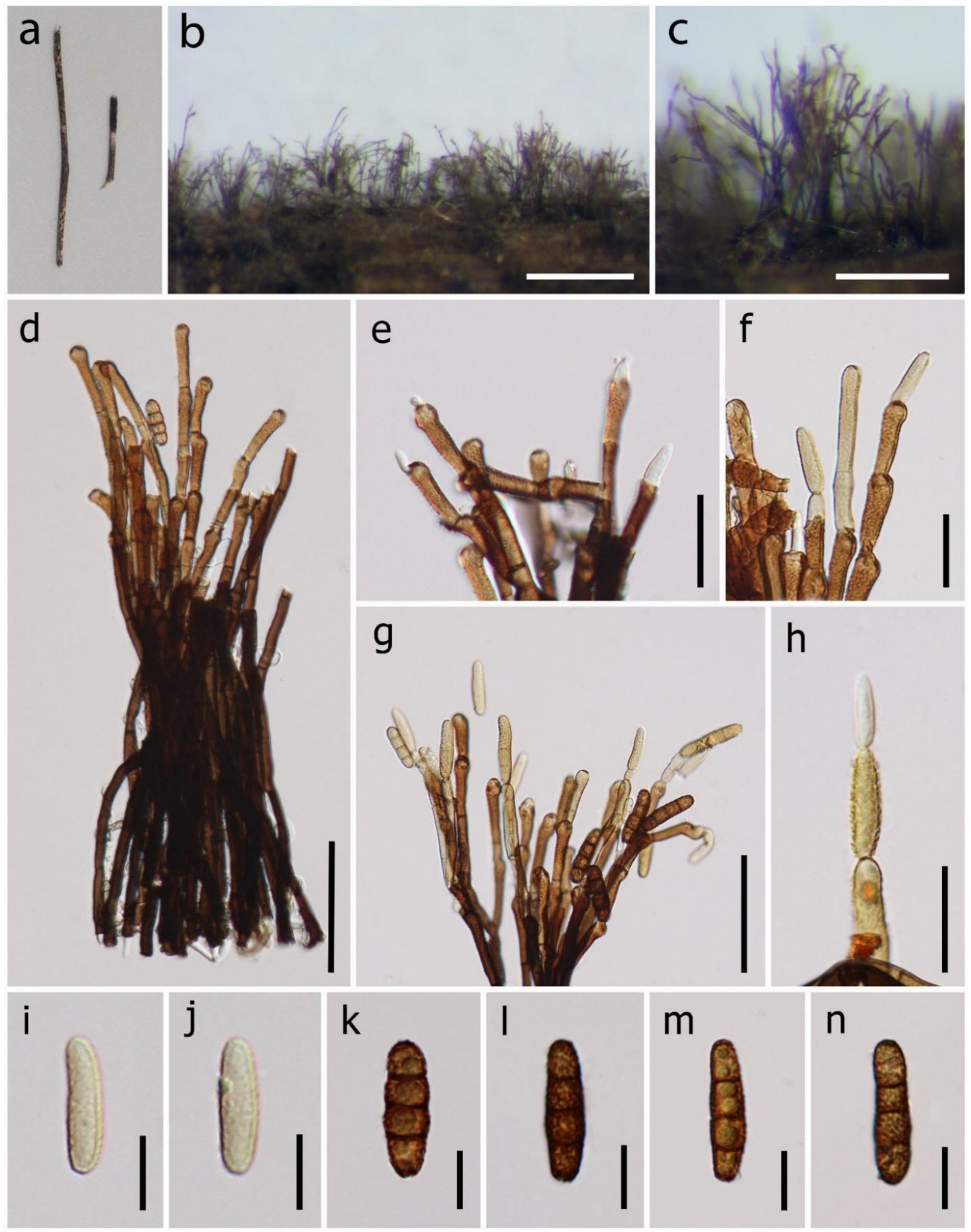

Figure 2 Dendryphiella fasciculata (MFLU 17-0748, holotype). a Specimens. b, c Colonies on

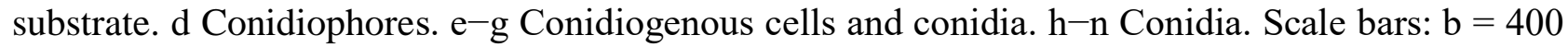
$\mu \mathrm{m}, \mathrm{c}=200 \mu \mathrm{m}, \mathrm{d}=50 \mu \mathrm{m}, \mathrm{e}=25 \mu \mathrm{m}, \mathrm{f}, \mathrm{h}=20 \mu \mathrm{m}, \mathrm{g}=50 \mu \mathrm{m}, \mathrm{i}-\mathrm{n}=10 \mu \mathrm{m}$. 
catenate in acropetal chain, fusiform to ellipsoidal, rounded at apex, truncate at base, pale brown, aseptate when young, brown or dark brown, 3-septate when mature, slightly constricted at septa, thick-walled, verrucose. Sexual morph: Unknown.

Culture characters - Conidia germinated on WA (Water Agar) within 24 hours. One or two germ tubes produced from both ends. Colonies reached about $5 \mathrm{~cm}$ diameter after 1 week on PDA at $25{ }^{\circ} \mathrm{C}$. Mycelia are superficial, with entire edge, floccose at the center, white to light brown from above and light brown from below.

Material examined - Thailand, Chiang Mai Province, on decaying wood, 27 September 2016, Chuangen Lin, Lin 03-1 (MFLU 17-0748, holotype; HKAS 99519, isotype) - ex-type living culture MFLUCC 17-1074

Notes - Dendryphiella fasciculata resembles D. aspera, D. broussonetiae, and D. lycopersicifolia in having fasciculate conidiophores. However, D. aspera occasionally has fasciculate conidiophores and D. fasciculata differs from D. broussonetiae and D. lycopersicifolia in having 3-septate conidia when mature, while the latter two are mostly 1-septate and 0-1-3septate respectively. Dendryphiella fasciculata has brown conidia, while those of $D$. broussonetiae and D. lycopersicifolia are olivaceous. Moreover, D. lycopersicifolia has larger conidiophores and conidia than those of $D$. fasciculata (up to 500 vs up to $250 \mu \mathrm{m}$ and $12-58 \times 4-8$ vs $15-30 \times$ 4.3-7.4 $\mu \mathrm{m}$ ). Phylogenetic analysis showed that D. fasciculata is phylogenetically distinct from other Dendryphiella species.

\section{Notes on currently accepted species of Dendryphiella}

1. Dendryphiella aspera R.W. Barreto \& J.C. David, Mycological Research 99 (7): 7701995. Description and illustrations - See Barreto et al. (1995)

Notes - Dendryphiella aspera was introduced by Barreto et al. (1995) on Lantana camara in Brazil. This species has rough-walled conidiophores which are distinct form other species. See note on D. dregeae. Type material of this species is IMI 345366.

2. Dendryphiella broussonetiae Y.L. Guo \& Z.Y. Zhang, Mycosystema 18 (3): 2361999.

Description and illustrations - See Guo \& Zhang (1999)

Notes - This species was reported on Broussonetia papyrifera (Moraceae) by Guo \& Zhang (1999). The conidiophores in $D$. broussonetiae are similar to those of $D$. lycopersicifolia and $D$. fasciculata, but conidia are mostly 1-septate, which in D. lycopersicifolia they are 0-1-3-septate and in D. fasciculata aseptate when young and 3-septate when mature. Type material of this species is MHYAU 03898.

3. Dendryphiella dregeae A.N. Rai \& Kamal, Kavaka 14 (1-2): 311987.

Description and illustrations - See Rai \& Kamal (1986)

Notes - Rai \& Kamal (1986) reported this taxon on living leaves of Dregea volubilis (Asclepiadaceae). The conidia of $D$. dregeae share similar characters with $D$. aspera, but are distinct in conidial colour. Moreover basal cells of conidiophores in $D$. dregeae are peltate to irregularly lobed. Type material of this species is IMI 254686.

4. Dendryphiella eucalypti Matsush., Matsushima Mycological Memoirs 3: 91983.

Description and illustrations - See Matsushima (1983)

Notes - Matsushima (1983) introduced Dendryphiella eucalypti from leaf litter of Eucalypti sp. in Taiwan. Dendryphiella eucalypti and D. infuscans have pale brown conidia which distinctly differ in size. Dendryphiella eucalypti is $(15-) 17.5-25(-30) \times(4-) 4.5-6 \mu \mathrm{m}$ and the latter is smaller and 9-16 $\times 4-7 \mu \mathrm{m}$. Moreover, D. eucalypti has mostly 3-septate conidia, while $D$. infuscans has 0-2septate conidia. Type material of this species is MFC-6685.

5. Dendryphiella eucalyptorum Crous \& E. Rubio, Persoonia 32: 2312014. 
Description and illustrations - See Crous et al. (2014)

Notes - Crous et al. (2014) introduced D. eucalyptorum on small branches of Eucalyptus globulus (Myrtaceae). Dendryphiella eucalyptorum and D. paravinosa share similar characters of conidiophores in being branched above and below and both conidiophores are verruculose. However, D. eucalyptorum has longer conidiophores than D. paravinosa (up to 500 vs up to 150 $\mu \mathrm{m})$. Type material of this species is CBS H-21699.

6. Dendryphiella indica V. Rao \& Narania, Current Science 43 (16): 5251974.

Description and illustrations - See Rao \& Narania (1974)

Notes - Rao \& Narania (1974) reported this taxon on dead leaves of Aloe spp. Conidia of D. indica are morphologically similar to those of type species $D$. vinosa, but differs in conidiophores. Conidiophores of $D$. indica are branched, while the type species are simple or branched. Type collection of this species is in Herb. V.V.C.B.L. No. 1301.

7. Dendryphiella infuscans (Thüm.) M.B. Ellis, Dematiaceous Hyphomycetes: 5001971.

= Cladosporium infuscans Thüm., Revue mycol., 1: 591879.

Description and illustrations - See Ellis (1971)

Notes - see note on D. eucalypti.

8. Dendryphiella lycopersicifolia Bat. \& Peres, Memórias da Sociedade Broteriana 14: 831961. Description and illustrations - See Batista \& Peres (1961)

Notes - see notes on D. fasciculata and D. broussonetiae. Type material of this species is IMUR 17333

9. Dendryphiella paravinosa Crous \& Guarnaccia, Persoonia 36: 3372016.

Description and illustrations - See Crous et al. (2016)

Notes - Crous et al. (2016) introduced this species on leaves of Citrus sinensis (Rutaceae). See note on D. eucalyptorum. Type material of this species is CBS H-22595.

10. Dendryphiella uniseptata Matsush., Microfungi of the Solomon Islands and Papua-New Guinea: 231971.

Description and illustrations - See Matsushima (1971)

Notes - Matsushima (1971) introduced this taxon on Fici sp. Dendryphiella uniseptata have branched or unbranched conidiophores, which are similar than D. dregeae, D. infuscans and D. vinosa. However they differ in conidial septa and colour. Type material of this species is MFC2879.

11. Dendryphiella vinosa (Berk. \&M.A. Curtis) Reisinger, Bull. trimest. Soc. mycol. Fr.84: 27 1968.

= Helminthosporium vinosum Berk. \& Curt., in Berkeley, Jl. Linn. Soc. (Bot.), 10: 3611869.

= Dendryphiella interseminata (Berk. \& Rav.) Bubak \& Ranojevic, Ann. mycol., Berl., 12:

4171914.

= Dendrophion nodulosum Saccardo, Michelia, 1: 811877.

Description and illustrations - See Ellis (1971) and Matsushima (1971)

Notes $-D$. vinosa is the type species of Dendryphiella that occur commonly on the lower parts of dead or old herbaceous stems (Ellis 1971). Ellis (1971) described the species having 3-septate conidia, while Matsushima (1971) described the conidia as $(0-) 3(-5)$-septate. The conidia of $D$. vinosa are morphologically similar to $D$. fasciculata in conidial size $(17-30 \times 5-8 \mu \mathrm{m}$ vs. $15-30 \times$ 4.3-7.4 $\mu \mathrm{m})$. However, D. vinosa develops light brown conidia and conidia are formed in simple or branched chains, while D. fasciculata has conidia pale brown, aseptate when young, brown or dark brown, 3-septate when mature and conidia are formed in simple chains. Moreover, they differ 
distinctly in conidiophores. The type species has simple or branched conidiophores, while the latter's are unbranched and fasciculate in loose. Type material of this species is MFC- 2830.

\section{Notes on currently excluded species of Dendryphiella}

1. Paradendryphiella arenariae (Nicot) Woudenb. \& Crous, comb. nov. Studies in Mycology 75: 2082013.

$\equiv$ Dendryphiella arenariae Nicot, [as "arenaria"] Rev. Mycol. (Paris) 23: 93, 1958.

EScolecobasidium arenarium (Nicot) M.B. Ellis, More dematiaceoushyphomycetes (Kew): 194, 1976.

Description and illustrations - See Pugh \& Nicot (1964) and Woudenberg et al. (2013)

Notes - Woudenberg et al. (2013) proposed Dendryphiella arenariaeas a synonym of Paradendryphiella arenaria, and this species is currently residing in Pleosporaceae.

2. Paradendryphiella salina (G.K. Sutherl.) Woudenb. \& Crous, comb. nov. Studies in Mycology 75: 2072013.

$\equiv$ Cercospora salina G.K. Sutherl., New Phytol. 15: 431916.

$\equiv$ Dendryphiella salina (G.K. Sutherl.) Pugh \& Nicot, Trans. Brit. Mycol. Soc. 47(2): 266 1964.

EScolecobasidium salinum (G.K. Sutherl.) M.B. Ellis, More dematiaceous hyphomycetes (Kew): 1921976.

= Embellisia annulata de Hoog, Seigle-Mur., Steiman \& K.-E. Erikss., Antonie van Leeuwenhoek J. Microbiol. Serol. 51: 4091985.

Description and illustrations - See Pugh and Nicot (1964) and Woudenberg et al. (2013)

Notes - Woudenberg et al. (2013) synonymized Dendryphiella salina under Paradendryphiella (as a current name Paradendryphiella salina) based on morphological and molecular evidence. It is morphologically distinct from Dendryphiella species in having conidiogenous cells with denticles aggregated at the apex. Phylogenetic analysis places it in the family Pleosporaceae.

\section{Key to Dendryphiella species}

1. Conidiophores are fasciculate 2

1. Conidiophores mostly are solitary 3

2. Conidia 0 -spetate and pale brown when young, 3 -septate and brown when mature..D. fasciculata

2. Conidia 0-3-septate, mostly 1-septate, conidiophores $129-303 \mu \mathrm{m}$ long... D. broussonetiae

2. Conidia 0-1-3-septate, conidiophores $100-500 \mu \mathrm{m}$ long D. lycopersicifolia

3. Conidiophores are occasionally in loose groups D. aspera

3. Conidiophores are solitary 4

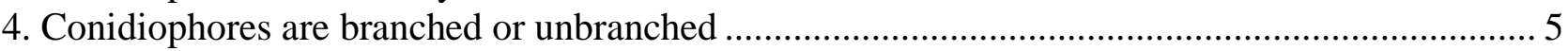

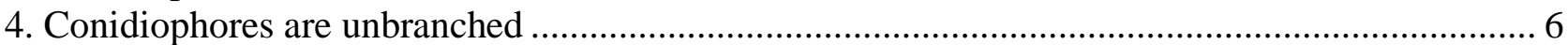

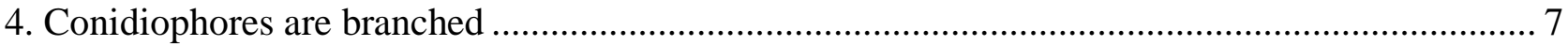

5. Conidia are 0-3-septate, subhyaline to light olivaceous, basal cells of conidiophores peltate to irregularly lobed. D. dregeae

5. Conidia are $0-2$-septate, pale brown D. infuscans

5. Conidia are 1(-2)-septate, pale olivaceous D. uniseptata

5. Conidia are $(0-) 3(-5)$-septate, light brown D. vinosa

6. Conidia are 1-4-septate, mostly 3 -septate, pale brown D. eucalypti

7. Conidiophores branched above and below, verruculose, up to $500 \mu \mathrm{m}$ long, conidia (1-)3(-5)septate, $(19-) 20-23(-25) \times 5(-7) \mu \mathrm{m}$.

D. eucalyptorum 7. Conidiophores branched above and below, verruculose, up to $150 \mu \mathrm{m}$ long, conidia (1-)3septate, $\left(10^{-}\right) 24-27(-33) \times\left(6^{-}\right) 7(-7.5) \mu \mathrm{m}$. D. paravinosa 7. Conidiophores smooth or verruculose, conidia 1-3-septate, $15-30 \times 5-9 \mu \mathrm{m}$ D. indica 


\section{Discussion}

In this study, a new Dendryphiella species is introduced and all eleven hitherto accepted species and two excluded species in the genus are provided with notes. Dendryphiella is a distinct genus in Dictyosporiaceae (Boonmee et al. 2016). Other asexual morph genera in this family form blastic conidiogenous cells, while Dendryphiella forms tretic conidiogenous cells. Boonmee et al. (2016) performed phylogenetic analyses based on DNA sequence data for three loci (SSU, LSU, TEF1- $\alpha$ ). The result showed that Dendryphiella is a distinct genus in Dictyosporiaceae. In our phylogenetic tree, $D$. vinosa and $D$. eucalyptorum can phylogenetically represent the same species. This might be because only LSU gene data is available for these two species, and in NCBI blast result on LSU, sequences of D. eucalyptorum is $821 / 821$ (100\%) similar to D. vinosa without gaps. This situation is common in phylogenetic studies (Crous et al. 2014). Additional molecular sequence data is needed for resolve for these two species. However, morphologically they can be distinguished from each other. Dendryphiella vinosa formed simple or branched conidiophores, while those of D. eucalyptorum are branched above and below. Additionally, the conidiophores of D. eucalyptorum are longer and narrower (up to $500 \mu \mathrm{m}$ long, 3-5 $\mu \mathrm{m}$ wide), than those of $D$. vinosa (up to $450 \mu \mathrm{m}$ long, $4.5-7 \mu \mathrm{m}$ wide).

Dendryphiella and Dendryphion are distinguishable from each other. Dendryphion is characterized by usually apically branched conidiophores, terminal and intercalary, tretic conidiogenous cells and simple or branched, cylindrical or obclavate, sometimes cheiroid conidia formed in chains (Ellis 1971, Ellis 1976, Seifert et al. 2011, Su et al. 2016). In addition, phylogenetic study based on DNA sequence data places Dendryphion in Torulaceae (Crous et al. 2015, Su et al. 2016, Li et al. 2017), while Dendryphiella formed a distinct clade in Dictyosporiaceae (Boonmee et al. 2016).

In conclusion, this study serves as an update for future taxonomic studies of Dendryphiella. There is only sequence data available for four species. Additional sequence data is therefore required.

\section{Acknowledgements}

The authors would like to thank the Featured microbial resources and diversity investigation in Southwest Karst area (2014FY120100). This research is financially supported by Ph.D. research scholarship from Faculty of Agriculture, Natural Resources and Environment, Naresuan University.

\section{References}

Barreto RW, Evans HC, Ellison CA. 1995 - The mycobiota of the weed Lantana camara in Brazil, with particular reference to biological control. Mycological Research 99(7), 769-782.

Batista AC, Peres GEP. 1961 - Alguns Melanconiales e Moniliale. Memórias da Sociedade Broteriana 14, 83-94.

Boonmee S, D'souza MJ, Luo ZL, Pinruan U et al. 2016 - Dictyosporiaceae fam. nov. Fungal Diversity 80, 457-482.

Cai L, Zhang K, McKenzie EHC, Ho WH, Hyde KD. 2002 - Acrodictys liputii sp. nov. and Digitodesmium bambusicola sp. nov. from bamboo submerged in the Liput River in the Philippines. Nova Hedwigia 75, 525-532.

Chomnunti P, Hongsanan S, Aguirre-Hudson B, Tian Q et al. 2014 - The sooty moulds. Fungal Diversity 66, 1-36.

Crous PW, Shivas RG, Quaedvlieg W, Van der Bank M et al. 2014 - Fungal Planet description sheets: 214-280. Persoonia 32, 184-306.

Crous PW, Carris LM, Giraldo A, Groenewald JZ et al. 2015 - The genera of fungi-fixing the application of the type species of generic names-G 2: Allantophomopsis, Latorua, Macrodiplodiopsis, Macrohilum, Milospium, Protostegia, Pyricularia, Robillarda, Rotula, Septoriella, Torula, and Wojnowicia. IMA Fungus 6, 163-198.

Crous PW, Wingfield MJ, Richardson DM, Le Roux JJ et al. 2016 - Fungal Planet description 
sheets: 400-468. Persoonia 36, 316-458.

Ellis MB. 1971 - Dematiaceous hyphomycetes. Commonwealth Mycological Institute, Kew, Surrey, England.

Ellis MB. 1976 - More Dematiaceous Hyphomycetes. Commonwealth Mycological Institute, Kew, Surrey, England.

Goh TK, Hyde KD, Ho WH. 1999 - A revision of the genus Dictyosporium, with descriptions of three new species. Fungal Diversity 2, 65-100.

Guo YL, Zhang ZY. 1999 - A new species of Dendryphiella. Mycosystema 18, 236-237.

Hall TA. 1999 - BioEdit: a user-friendly biological sequence alignment editor and analysis program for Windows 95/98/NT. In: Nucleic Acids Symposium Series, pp 95-98.

Hillis DM, Bull JJ. 1993 - An empirical test of bootstrapping as a method for assessing confidence in phylogenetic analysis. Systematic Biology 42, 182-192.

Hughes SJ. 1953 - Conidiophores, conidia, and classification. Canadian Journal of Botany 31, 577659.

Jayasiri SC, Hyde KD, Ariyawansa HA, Bhat DJ et al. 2015 - The Faces of Fungi database: fungal names linked with morphology, phylogeny and human impacts. Fungal Diversity 74, 3-18.

Jones EBG, Klaysuban A, Pang KL. 2008 - Ribosomal DNA phylogeny of marine anamorphic fungi: Cumulospora varia, Dendryphiella species and Orbimyces spectabilis. The Raffles Bulletin of Zoology 19 (suppl.), 11-18.

Jones EBG, Suetrong S, Sakayaroj J, Bahkali AH et al. 2015 - Classification of marine Ascomycota, Basidiomycota, Blastocladiomycota and Chytridiomycota. Fungal Diversity 73, $1-72$.

Katoh K, Standley DM. 2013 - MAFFT multiple sequence alignment software version 7: improvements in performance and usability. Molecular Biology and Evolution 30, 772-780.

Kirk PW, Jr. 1983 - Direct enumeration of marine arenicolous fungi. Mycologia 75, 670-682.

Kohlmeyer J. 1966 - Ecological observations on arenicolous marine fungi. Zeitschrift für allgemeine Mikrobiologie 6, 95-106.

Kohlmeyer J, Kohlmeyer E. 1979 - Marine mycology: the higher fungi. Elsevier, New York.

Larsson A. 2014 - AliView: a fast and lightweight alignment viewer and editor for large datasets. Bioinformatics 30, 3276-3278.

Li JF, Phookamsak R, Jeewon R, Bhat DJ et al. 2017 - Molecular taxonomy and morphological characterization reveal new species and new host records of Torula species (Torulaceae, Pleosporales). Mycological Progress 16, 447-461.

Liu JK, Hyde KD, Jones EBG, Ariyawansa HA et al. 2015 - Fungal diversity notes 1-110: taxonomic and phylogenetic contributions to fungal species. Fungal Diversity 72, 1-197.

Matsushima T. 1971 - Microfungi of the Solomon Islands and Papua-New Guinea. Published by the author, Kobe, Japan.

Matsushima T. 1983 - Matsushima Mycological Memoirs No. 3. Published by the author, Kobe, Japan..

Miller MA, Pfeiffer W, Schwartz T. 2010 - "Creating the CIPRES Science Gateway for inference of large phylogenetic trees" in Proceeding of the Gateway Computing Environments Workshop (GCE), 14 Nov. 2010, New Orleans, LA pp1-8.

Nicot J. 1958 - Une moisissure arenicole du littoral atlantique: Dendryphiella arenaria sp. nov. Revue de Mycologie 23, 87-99.

Page RDM. 1996 - TreeView: an application to display phylogenetic trees on personal computer. Computer Applications in the Biosciences 12, 357-358.

Phookamsak R, Liu JK, McKenzie EHC, Manamgoda DS et al. 2014 - Revision of Phaeosphaeriaceae. Fungal Diversity 68, 159-238.

Pugh GJF, Nicot J. 1964 - Studies on fungi in coastal soils: V. Dendryphiella salina (Sutherland) comb. nov. Transactions of the British Mycological Society 47, 263-267.

Rai AN, Kamal. 1986 - Fungi of Gorakhpur-XLII. Kavaka 14(1-2), 31-36.

Rannala B, Yang Z. 1996 - Probability distribution of molecular evolutionary trees: a new method 
of phylogenetic inference. Journal of Molecular Evolution 43, 304-311.

Ranojevic Nv. 1914 - Dritter beitrag zur pilzflora serbiens. Annales Mycologici 12, 393-421.

Rao V, Narania K. 1974 - A new species of Dendryphiella. Current Science 43, 525-526.

Reisinger O. 1968 - Remarques sur les genres Dendryphiella et Dendryphion. Bulletin de la Société Mycologique de France 84, 27-51.

Ronquist F, Teslenko M, Van der Mark, Ayres DL et al. 2012 - MrBayes 3.2: Efficient Bayesian phylogenetic inference and model choice across a large model space. Systematic Biology 61, 539-542.

Seifert K, Morgan-Jones G, Gams W, Kendrick B. 2011 - The genera of Hyphomycetes. CBSKNAW Fungal Biodiversity Centre, Utrecht, The Netherlands.

Su HY, Hyde KD, Maharachchikumbura SSN, Ariyawansa HA et al. 2016 - The families Distoseptisporaceae fam. nov., Kirschsteiniotheliaceae, Sporormiaceae and Torulaceae, with new species from freshwater in Yunnan Province, China. Fungal Diversity 80, 375-409.

Swofford DL. 2002 - PAUP*: phylogenetic analysis using parsimony (and other methods), version 4.0 b10. . Sunderland, Massachusetts: Sinauer Associates Google Scholar.

Tanaka K, Hirayama K, Yonezawa H, Sato G et al. 2015 - Revision of the Massarineae (Pleosporales, Dothideomycetes). Studies in Mycology 82, 75-136.

Vilgalys R, Hester M. 1990 - Rapid genetic identification and mapping of enzymatically amplified ribosomal DNA from several Cryptococcus species. Journal of Bacteriology 172, 4238-4246.

Wang R-X, Luo Z-L, Hyde KD, Bhat JD et al. 2016 - New species and records of Dictyocheirospora from submerged wood in north-western Yunnan, China. Mycosphere 7, 1357-1367.

White TJ, Bruns T, Lee SJWT, Taylor JW. 1990 - Amplification and direct sequencing of fungal ribosomal RNA genes for phylogenetics. In: Innis MA, Gelfand DH, Sninsky JJ, White TJ, eds. PCR protocols: a guide to methods and applications. California, Academic Press. p. 315322.

Wijayawardene DNN, McKenzie EHC, Hyde KD. 2012 - Towards incorporating anamorphic fungi in a natural classification-checklist and notes for 2011. Mycosphere 3, 157-228.

Woudenberg JHC, Groenewald JZ, Binder M, Crous PW. 2013 - Alternaria redefined. Studies in Mycology 75, 171-212. 